\title{
Rising trends in Caesarean section in 6 Egyptian governorates
}

Maha Wahdan, ${ }^{1}$ Sally Hakim, ${ }^{1}$ Maha El Gaafary, ${ }_{1}^{1}$ Dalia Sos, ${ }^{1}$ Ghada Wassif, ${ }^{1}$ Wafaa Hussein, ${ }^{1}$ Amany Mokhtar, ${ }^{1}$ Amr Hussein, ${ }^{2}$ Mohamed El Awady, Mervat Rady ${ }^{1}$ and Wagida Anwar ${ }^{1}$

${ }^{1}$ Department of Community, Environmental and Occupational Medicine, Faculty of Medicine, Ain Shams University, Cairo, Egypt (Correspondence to: M. Wahdan: drmaha_wahdan@med.asu.edu.eg). ${ }^{2}$ Department of Obstetrics and Gynaecology, Faculty of Medicine, Cairo University, Cairo, Egypt

\begin{abstract}
Background: Caesarean section (CS) is a life-saving operation when vaginal delivery is risky to the mother or baby. However, if not medically indicated or performed under suboptimal conditions, it can be harmful and resource-intensive.

Aims: To estimate the prevalence of CS in 6 Egyptian governorates and identify possible risk factors (including demographic, social and healthcare services factors) stratified according to geographical areas.

Methods: We used secondary data collected from a large survey to investigate the sociodemographic and health indicators of 6 purposefully selected Egyptian governorates with suboptimal health indicators: 3 from Upper Egypt (Sohag, Assiut and Menia) and 3 from Lower Egypt (Sharkia, Beheira and Ismailia). The survey data were gathered using an interview questionnaire that targeted household members.

Results: The CS rate was estimated at $55.1 \%$ for the 3 years preceding the study, and the highest rate was $67.8 \%$ in Behira and the lowest was $49.0 \%$ in Assiut. In most governorates, the CS rate was higher in rural than in urban areas, but the difference was not significant. High CS rates were significantly related to higher social class and lower number of children $(\leq 3)$.

Conclusion: In the governorates investigated, CS was performed more often, with higher rates than those reported in the 2015 Egypt Health Issue Survey. The adoption of protocols for elective CS should be enforced with a more multisectoral effort. Pregnant women should be well informed of the risks associated with CS and its medical indications.

Keywords: caesarean section, Egypt, epidemiology, risk factors, sociodemographic factors

Citation: Wahdan M; Hakim S; El Gaafary M; Sos D; Wassif G; Hussein W. et al. Rising trends in delivery mode in 6 Egyptian governorates. East Mediterr Health J. 2022;28(5):336-344. https://doi.org/10.26719/emhj.22.012

Received: 04/06/20; accepted: 13/10/21

Copyright (C) World Health Organization (WHO) 2022. Open Access. Some rights reserved. This work is available under the CC BY-NC-SA 3.0 IGO license (https://creativecommons.org/licenses/by-nc-sa/3.o/igo)
\end{abstract}

\section{Introduction}

Caesarean section (CS) is a major surgical operation aimed at saving the lives of mothers and their children under conditions of obstetric risk. CSs are justified under certain circumstances, such as cephalopelvic disproportion and contracted pelvis; dystocia due to pelvic or soft tissue abnormalities; inadequate uterine contractions; antepartum haemorrhage; pre-eclamptic toxaemia; eclampsia; fetal distress and cord prolapse; malpresentation; and maternal diseases, such as heart disease, complicated obstetric history, habitual intrauterine fetal death, and elderly primigravida (1).

Unfortunately, besides these medical reasons, others, such as institutional and physician-related factors, may affect the frequency of CS. For example, the availability of facilities and trained obstetricians, patient affordability, place of birth (private or public sector), physician practice styles, and the obstetrician's clinical attitude and fear of litigation. However, CSs are not always entirely associated with health-facility- or physician-related factors. Patients also opt for CS to avoid the pain of labour or because of the belief that vaginal delivery will negatively affect a woman's future sexual performance and her husband's sexual pleasure (1).

The World Health Organization (WHO) considers a population-based rate of CS of $10-15 \%$ as the ideal rate associated with a notable decline in maternal mortality ratio and neonatal mortality rate (2). However, the global rate of CS continues to rise, leading to increased health service costs and risks of maternal and perinatal morbidity and mortality. The CS rate differs among countries (Western Europe, 24.5\%; North America, 32\%; and South America, 41\%) and is related to socioeconomic conditions. Furthermore, the rates are higher in more-developed regions (27.2\%) than in extremely underdeveloped regions $(6.0 \%)(3-5)$.

In high-income countries, the increased CS trend may be because short-term adverse maternal outcomes of CS, such as infection, haemorrhage, visceral injury, and venous thromboembolism, have been minimized, and CS is therefore considered safe. However, in lowand middle-income countries, there is an increased risk of adverse short-term maternal outcomes, even with CS without medical indication. There are long-term risks of caesarean delivery for mother, baby, and subsequent pregnancies (4).

In Egypt, the proportion of CSs has been steadily increasing in recent years and has reached an alarming level. The proportion of CSs documented in the 2014 Egyptian Demographic Health Survey (EDHS) was $51.8 \%$, which was 4 times the maximum threshold recommended by the WHO (6). In the 2015 Egypt Health Issue Survey, the rate reached $43.8 \%$ and CS rates in the 6 governorates targeted in the present study were high $(34.8-56 \%)(7)$.

This study aimed to estimate the prevalence of CS in 6 Egyptian governorates and to identify possible risk factors (including demographic, social and healthcare 
services factors) stratified according to geographical areas.

\section{Methods}

\section{Study design and setting}

This was a cross-sectional study derived from a large survey that assessed multiple alarming health indicators implemented from May to September 2017. The survey was conducted in 6 purposefully selected Egyptian governorates: 3 from Upper Egypt (Sohag, Assiut and Menia) and 3 from Lower Egypt (Sharkia, Behira and Ismailia) as they were previously identified by the National Population Council (NPC) as having the worst socioeconomic and health indicators.

\section{Study population}

Study participants included ever-married women aged 15-49 years who had given birth in the past 3 years prior to the survey.

\section{Sample size}

The sample size for the original survey considered the nearest indicator to $50 \%$ (which is the rate of use of family planning methods) that led to a larger sample size, taking into account the size of the population in each province. Hence, the total sample size in each governorate in Upper and Lower Egypt was 2000 households for Behira, Minya, Assiut and Sohag; 2500 for Sharkia; and 600 for Ismailia, at a $95 \%$ confidence level, $2 \%$ margin of error, and a design effect of 2.o. Calculation of the sample size to estimate CS prevalence was similar to that determined for family planning, as the prevalence of CS, referring to earlier research in Egypt was close to that of family planning (51.8\%) according to EDHS 2014. Sample size was 61 in Menia, 105 in Sohag, 146 in Behira, 172 in Ismailia, 489 in Sharkia and 512 in Sohag. For the smallest sample size $(n=61)$ the margin of error did not exceed $10 \%$ and the confidence level was not less than $90 \%$. A total of $1508 \mathrm{ev}$ er-married women aged 15-49 years who had given birth in the past 3 years were interviewed, and after removing those with missing data, 1488 ever-married women aged $15-49$ years who had given birth in the previous 3 years were included in our analysis.

\section{Sampling method}

In the original survey, a simple random sample from the Central Agency for Public Mobilization and Statistics (CAPMAS) representing the target 6 governorates was used. The sample was presented as 100-125 clusters, and each cluster included 20 family households, defined by the name of the head of each family and distributed geographically in terms of rural and urban areas and centres, departments, villages, and different districts according to the Egyptian census of 2006. A household (sampling unit) was defined as $\geq 2$ persons living in 1 house and economically sharing a single comprehensive dwelling. All age groups and genders were included. We selected all participants eligible to assess CS and the associated risk factors (ever-married women aged 15-49 years old, then selection of those who had given birth in the 3 years prior to the survey).

\section{Data collection tool}

We used secondary data collected from a large survey to investigate the sociodemographic and health indicators of 6 purposefully selected Egyptian governates. The original data were collected using a structured questionnaire via face-to-face interviews, designed to fulfil different survey objectives, including CS and its different determinants in terms of sociodemographic, economic and health service factors. The original data were collected by nurses and Raadat Refeyat (field healthcare providers). They were supervised by the NPC team in the different governorates. The structured questionnaire comprised 2 sections: 1) sociodemographic data (age, early marriage, marital status, educational level, occupational status, and social class); and 2) medical and obstetric history (chronic diseases, pregnancy in the last 3 years, antenatal care, place of delivery, postnatal care, neonatal mortality, and post-neonatal mortality).

\section{Data management and statistical analysis}

The original data collected from all 6 governorates were coded and entered using a double entry technique into Census and Survey Processing System (CSPro) 7.0 statistical software (https://www.census.gov/data/software/ cspro.html). The research team conducted several workshops to develop the final structure of the CSPro database. This included ensuring minimal data entry errors by implementing validation rules and organizing the data in a manner that facilitated their later use as a baseline for further NPC studies.

Statistical analysis was performed using SPSS version2o (IBM Corp., Armonk, NY, USA). For descriptive analyses, categorical (qualitative) data were presented as frequencies and percentages, and comparisons were made using $\chi^{2}$ and Fisher's exact tests. The odds ratio was calculated with a $95 \%$ confidence interval.

\section{Data quality assurance plan in the original survey}

To minimize the possible bias that could occur during the study, the following steps were taken. 1) During designing the questionnaire: items were reviewed, and a pilot study was conducted in Bilbes City, Sharkia Governorate to estimate the time required to complete the questionnaire, and to test comprehensibility and acceptance of questions by responders. 2) As regards information about CS, there was no information bias as it is a well-recognized procedure that was well recalled by the interviewed women. 3) Training sessions: data collectors (field healthcare provider such as nurses and Raadat Refeyat) and field supervisors were trained on questionnaire completion, and their practice in data collection was assessed to ensure comprehensiveness. 4) Field monitoring process: during data collection, every 10 data collectors were in contact with field supervisors for checking data quality 
and completeness. Field supervisors were always present to help identify and resolve field problems and to share feedback with the team leader and other field supervisors. 5) Desk revision of data sheets (questionnaires) was conducted during the process of data coding and entry: data were coded by trained data coders and a double entry process was used to check consistency. Data were double checked with other questions that verified the validity of the collected information. Validation rules on CSPro were set to limit the extent of errors during data entry. Data were cleared and checked for outliers.

\section{Ethical considerations}

This study was approved by the Ethical Committee of the Faculty of Medicine, Ain Shams University, Egypt, prior to study commencement. Administrative approvals and technical support were obtained from the NPC and CAPMAS. Written informed consent was obtained from all participants. Privacy and confidentiality were maintained according to the Revised Declaration of Helsinki on Biomedical Research Ethics (8).

\section{Results}

After eliminating those with incomplete data, $1488 \mathrm{ev}$ er-married women aged 15-49 years who gave birth in the previous 3 years were included in the analysis. Overall, the CS rate was (55.1\%). Behira had the highest CS rate $(67.8 \%)$, followed by Menia (63.9\%), Sharkia (59.1\%), Ismailia (57\%), Sohag (51.4\%) and Assuit (46.9\%). CS rate in Lower Egypt was significantly higher than in Upper Egypt (60.2\% vs 50.7\%), while there was no significant difference between rural and urban areas (56.5\% and 52.5\% respectively).

Data were analysed according to rural, urban (Table 1) and geographical area (Upper and Lower Egypt) (Table 2). In rural areas and Upper Egypt, univariate analysis revealed that a high CS rate was significantly associated with the younger age group (15-19 years). In rural areas, women with $\leq 3$ children, high socioeconomic status, and secondary school education or above had higher CS rates. In urban areas, high CS rate was only significantly associated with high socioeconomic status and those with $\leq 3$ children. However, none of the sociodemographic variables was found to be significantly associated with the CS rate in Lower Egypt.

AhighprevalenceofCShadasignificantassociationwith giving birth in private clinics rather than public hospitals in rural and urban areas (Table 3), and Upper Egypt(Table 4). Postpartum care was significantly associated with a higher CS rate in Upper and Lower Egypt (Table 4). There was no significant association between CS rate and neonatal or postnatal mortality, regardless of the geographic distribution.

\section{Discussion}

The current study shows that CS rate $55.1 \%$ in 6 selected Egyptian governates was higher than the rate in the
2014 EDHS (6), which showed that Caesarean deliveries accounted for half of all births in the 5 years preceding the survey. The rate was significantly higher than the estimate in the 2008 EDHS (9), which showed that CS accounted for $>25 \%$ of all deliveries in the 5 -year period prior to the survey. This indicates that the trend in CSs in Egypt has grown over time; more than indicated in the current research, which only covers the past 3 years rather than the 5 years covered by the EDHS.

When comparing the CS rates estimated in our study with those in other countries, Egypt had a higher rate than Jordan in 2017 (26\%) (10), Nigeria in 2018 (2.7\%) (11), Uganda in 2016 (6.2\%) (12), Ethiopia in 2016 (2\%) (13) and Pakistan in 2017 (22\%) (14). The same was observed when comparing the CS rate in our study with that in hospital-based studies. We found that the rate of CS was greater than that reported in hospitals in Ethiopia where CS rate in 1 hospital in 2011-2013 was $27.6 \%$ (15), and in another study in private and government hospitals, the rate in 2013 was $34.3 \%$ (16). This high prevalence may be attributed to the growing use of CS for convenience by women and doctors who want to arrange their deliveries for a specific time or day of the week. Also, it may possibly be due to the method used to calculate the CS rates, as the number of CSs in these countries could only reflect 1 year.

Our study shows that Lower Egypt had greater CS rates than Upper Egypt, as reported in the EDHS 2008 (9) and EDHS 2014 (6). Although the CS rate was greater in rural than in urban areas in the current study, the difference was not significant. This is consistent with the findings in Ethiopian hospitals from 2011 to 2013 (15). However, it contradicts earlier nationwide surveys in 2008 and 2014 in Egypt (6,9), Ethiopia in 2016 (13) and Uganda in 2016 (12) and in a household survey in India in 2011 (17).

When comparing rural with urban or Upper versus Lower Egypt, we discovered that the CS rate was significantly associated with younger age (15-19 years). This finding was inconsistent with that reported in the EDHS 2008 (9) and EDHS 2014 (6) as well as in Pakistan in 2014 (18) and Nigeria in 2013 (19), where the CS rate increased with age. However, in hospital-based studies in Libya between 2013 and 2016 (20) and Ethiopia between 2011 and 2013 (15), the CS rate was high in women aged 20-40 years. This may be because younger mothers are at high risk for delivery complications, have a fear of vaginal birth, and the belief that CS is safer. The discrepancy between our findings and those of earlier studies could be due to differences in cultural and social factors.

The CS rate in the current study was higher in women with a high education level in rural than in urban areas and in Upper than Lower Egypt. This pattern is similar to that reported in the EDHS 2008 (9) and EDHS 2014 (6), Ethiopia in 2016 (13), Uganda in 2016 (12), Pakistan in 2014 (18), Nigeria in 2013 (21), and a meta-analysis of CS rates in the Islamic Republic of Iran and Lebanon (22) in which the CS rates were higher for women with a high education level. 


\begin{tabular}{|c|c|c|c|c|}
\hline \multirow{2}{*}{ Variables } & \multirow{2}{*}{$\begin{array}{c}\text { Rural } \\
\text { CS } \\
\text { n (\%) }\end{array}$} & \multicolumn{3}{|c|}{ Urban } \\
\hline & & OR $(95 \% \mathrm{CI})$ & $\begin{array}{c}\text { CS } \\
n(\%)\end{array}$ & OR $(95 \% \mathrm{CI})$ \\
\hline \multicolumn{5}{|l|}{ Governorate } \\
\hline Sharkia & $263(59.8)$ & $1.5(0.9-2.3)$ & $26(53.1)$ & $4.5(0.9-23.5)$ \\
\hline Ismailia & $49(49.5)$ & 1.0 & $49(67.1)$ & $8.2^{*}(1.6-41.5)$ \\
\hline Behira & $95(67.9)$ & $2.2^{*}(1.3-3.7)$ & $4(66.7)$ & $8.0(0.8-79.7)$ \\
\hline Menia & $35(66.0)$ & $1.9(0.9-3.9)$ & $4(50.0)$ & $4.0(0.5-31.9)$ \\
\hline Assiut & $201(50.0)$ & $1.0(0.7-1.6)$ & $50(45.0)$ & $3.3(0.7-16.1)$ \\
\hline Sohag & $53(54.6)$ & $1.2(0.7-2.2)$ & $2(20.0)$ & 1.0 \\
\hline \multicolumn{5}{|l|}{ Age groups, yr } \\
\hline $15-19$ & $30(81.1)$ & $7.3^{*}(2.1-25.5)$ & $6(66.7)$ & $5.6(0.2-176.3)$ \\
\hline $20-24$ & $169(60.1)$ & $2.6(0.9-6.8)$ & $23(56.1)$ & $3.8(0.1-99.1)$ \\
\hline $25-29$ & $222(58.3)$ & $2.4(0.9-6.2)$ & $36(50.7)$ & $3.1(0.1-78.3)$ \\
\hline $30-34$ & $160(54.8)$ & $2.1(0.8-5.4)$ & $42(53.8)$ & $3.5(0.1-88.4)$ \\
\hline $35-39$ & $80(50.3)$ & $1.7(0.6-4.6)$ & $20(46.5)$ & $2.6(0.1-67.8)$ \\
\hline $40-44$ & $28(45.2)$ & $1.4(0.5-4.1)$ & $8(57.1)$ & $3.9(0.1-112.9)$ \\
\hline $45-49$ & $7(36.8)$ & 1.0 & $0(0.0)$ & 1.0 \\
\hline \multicolumn{5}{|l|}{ Education level } \\
\hline$<$ Secondary & $314(51.6)$ & 1.0 & $43(46.7)$ & 1.0 \\
\hline$\geq$ Secondary & $376(61.4)$ & $1.5^{*}(1.2-1.9)$ & $91(55.8)$ & $1.4(0.9-2.4)$ \\
\hline \multicolumn{5}{|l|}{ Occupation } \\
\hline Not working & $631(56.4)$ & 1.0 & 117 (52.9) & $1.1(0.6-2.3)$ \\
\hline Working & $65(58.0)$ & $1.1(0.7-1.6)$ & $18(50.0)$ & 1.0 \\
\hline \multicolumn{5}{|l|}{ Social class } \\
\hline Quantiles 1-3 & $375(52.6)$ & 1.0 & $34(39.5)$ & 1.0 \\
\hline Quantiles 4-5 & $321(62.0)$ & $1.5^{*}(1.2-1.8)$ & $101(59.1)$ & $2.2^{*}(1.3-3.8)$ \\
\hline \multicolumn{5}{|l|}{ Early marriage $^{a}$} \\
\hline No & 546 (57.9) & $1.3(0.9-1.7)$ & $117(53.2)$ & $1.2(0.6-2.4)$ \\
\hline Yes & $150(52.1)$ & 1.0 & $18(48.6)$ & 1.0 \\
\hline \multicolumn{5}{|l|}{ No. of children } \\
\hline None & 95 (57.9) & $1.5^{*}(1.1-2.3)$ & $10(52.6)$ & $1.5(0.6-4.2)$ \\
\hline$\leq 3$ & $445(60.7)$ & $1.8^{*}(1.4-2.3)$ & $91(58)$ & $1.9^{*}(1.1-3.3)$ \\
\hline$>3$ & $156(46.7)$ & 1.0 & $34(42)$ & 1.0 \\
\hline \multicolumn{5}{|l|}{ Chronic diseases" } \\
\hline No & $610(57.2)$ & $1.2(0.9-1.7)$ & $116(53.5)$ & $1.2(0.62 .3)$ \\
\hline Yes & $86(52.4)$ & 1.0 & $19(47.5)$ & 1.0 \\
\hline
\end{tabular}

*Statistically significant using the $\chi^{2}$ test, "statistically significant using Fisher's exact test. ${ }^{a}<18$ years old.

$C I=$ confidence interval $; C S=$ caesarean section; $O R=$ odds ratio .

CS rate was not significantly associated with maternal working status, but it was higher among nonworking women in urban areas and in Upper and Lower Egypt, and among working women in rural areas. This pattern contrasted that observed in the EDHS 2008 (9) and EDHS 2014 (6) in which the rate was greater among working women.

The current CS rate was associated with a higher socioeconomic level in different geographical areas (rural, urban, Upper and Lower Egypt), which was consistent with the EDHS 2008 (9) and EDHS 2014 (6), and a metaanalysis in the Islamic Republic of Iran and Lebanon (22). This is mostly because women of a high social class have the financial means to pay for a CS if they are concerned about prolonged labour or experiencing pain during vaginal delivery. Another reason could be the cultural belief that CS is a symbol of a higher social class.

Current CS rates in different geographical areas (rural, urban, Upper and Lower Egypt) were higher among women who had given birth to $\leq 3$ children. This was also 
Table 2 Factors associated with CS among ever-married women aged 15-49 years old with pregnancy within 3 years prior to the survey in Upper and Lower Egypt $(n=1488)$

\begin{tabular}{|c|c|c|c|c|}
\hline \multirow[t]{2}{*}{ Variables } & \multicolumn{2}{|c|}{ Upper Egypt } & \multicolumn{2}{|c|}{ Lower Egypt } \\
\hline & $\begin{array}{c}\text { CS } \\
\text { n (\%) }\end{array}$ & OR $(95 \% \mathrm{CI})$ & $\begin{array}{c}\text { CS } \\
\mathbf{n}(\%)\end{array}$ & OR $(95 \%$ CI $)$ \\
\hline \multicolumn{5}{|l|}{ Age group (yr) } \\
\hline $15-19$ & $18(78.3)$ & $9.6^{*}(1.8-50.3)$ & $18(78.3)$ & $4.5(0.9-23.3)$ \\
\hline $20-24$ & $80(59.3)$ & $3.8(0.9-15.3)$ & $112(59.9)$ & $1.9(0.5-7.2)$ \\
\hline $25-29$ & $99(52.7)$ & $2.9(0.8-11.5)$ & $159(60.2)$ & $1.9(0.5-7.2)$ \\
\hline $30-34$ & $86(47.8)$ & $2.4(0.6-9.5) 1$ & $116(61.1)$ & $1.9(0.5-7.5)$ \\
\hline $35-39$ & $39(39.0)$ & $1.7(0.4-6.8)$ & $61(59.8)$ & $1.9(0.5-7.3)$ \\
\hline $40-44$ & $20(45.5)$ & $2.2(0.5-9.5)$ & $16(50.0)$ & $1.3(0.3-5.5)$ \\
\hline $45-49$ & $3(27.3)$ & 1.0 & $4(44.4)$ & 1.0 \\
\hline \multicolumn{5}{|l|}{ Education level } \\
\hline$<$ Secondary & $189(45.9)$ & 1.0 & $168(58.3)$ & 1.0 \\
\hline$\geq$ Secondary & $153(58.8)$ & $1.7^{*}(1.2-2.3)$ & $314(61.0)$ & $1.1(0.8-1.5)$ \\
\hline \multicolumn{5}{|l|}{ Occupation } \\
\hline Not working & $264(51.4)$ & $1.1(0.8-1.6)$ & $399(61.5)$ & $1.3(0.9-1.9)$ \\
\hline Working & $81(48.5)$ & 1.0 & $87(55.1)$ & 1.0 \\
\hline \multicolumn{5}{|l|}{ Social class } \\
\hline Quintiles 1-3 & $251(47.4)$ & 1.0 & $158(58.7)$ & 1.0 \\
\hline Quintiles 4-5 & $94(62.3)$ & $1.8^{*}(1.3-2.7)$ & $328(61.0)$ & $1.1(0.8-1.5)$ \\
\hline \multicolumn{5}{|l|}{ Early marriage } \\
\hline No & $65(54.6)$ & 1.0 & $40(62.5)$ & 1.0 \\
\hline Yes & $119(60.7)$ & $1.3(0.8-2.0)$ & $214(63.1)$ & $1.0(0.6-1.8)$ \\
\hline \multicolumn{5}{|c|}{ Number of children } \\
\hline None & $63(54.6)$ & $1.8^{*}(1.2-2.9)$ & $40(62.5)$ & $1.2(0.7-2.3)$ \\
\hline$\leq 3$ & $182(58.7)$ & $1.8^{*}(1.3-2.5)$ & $354(61)$ & $1.2(0.9-1.7)$ \\
\hline$>3$ & $98(38.9)$ & 1.0 & $92(56.4)$ & 1.0 \\
\hline \multicolumn{5}{|l|}{ Chronic diseases" } \\
\hline No & $285(51.5)$ & $1.2(0.8-1.8)$ & $441(60.3)$ & $1.0(0.7-1.7)$ \\
\hline Yes & $60(46.9)$ & 1.0 & $45(59.2)$ & 1.0 \\
\hline
\end{tabular}

${ }^{*}$ statistically significant using the $\chi^{2}$ test, "statistically significant using Fisher's exact test.

$\mathrm{CI}=$ confidence interval; $\mathrm{CS}=$ caesarean section; $\mathrm{OR}=$ odds ratio.

Table 3 Health services utilization among ever-married women aged 15-49 years old with pregnancy within 3 years prior to survey by area of residence $(n=1488)$

\begin{tabular}{|c|c|c|c|c|}
\hline \multirow[t]{2}{*}{ Variables } & \multicolumn{2}{|c|}{ Rural } & \multicolumn{2}{|c|}{ Urban } \\
\hline & $\begin{array}{c}\text { CS } \\
\text { n (\%) }\end{array}$ & OR $(95 \%$ CI $)$ & $\begin{array}{c}\text { CS } \\
\text { n (\%) }\end{array}$ & OR $(95 \% \mathrm{CI})$ \\
\hline \multicolumn{5}{|l|}{ Antenatal care } \\
\hline No & $20(43.5)$ & 1.0 & $9(47.4)$ & 1.0 \\
\hline Yes & 674 (56.9) & $1.7(0.9-3.1)$ & 126 (52.9) & $1.2(0.5-3.2)$ \\
\hline \multicolumn{5}{|l|}{ Place of delivery } \\
\hline Private clinic & $414(66.1)$ & $1.4^{*}(1.1-1.9)$ & $84(61.8)$ & $1.8^{*}(1.0-3.2)$ \\
\hline Hospital & $208(57.5)$ & 1.0 & $36(47.4)$ & 1.0 \\
\hline
\end{tabular}

${ }^{*}$ statistically significant using the $\chi^{2}$ test, "statistically significant using Fisher's exact test.

$C I=$ confidence interval $; C S=$ caesarean section; $O R=$ odds ratio. 


\begin{tabular}{|c|c|c|c|c|}
\hline & \multicolumn{2}{|c|}{ Upper Egypt } & \multicolumn{2}{|c|}{ Lower Egypt } \\
\hline & $\begin{array}{c}\text { CS } \\
\text { n (\%) }\end{array}$ & OR $(95 \% \mathrm{CI})$ & $\begin{array}{c}\text { CS } \\
\text { n (\%) }\end{array}$ & OR $(95 \% \mathrm{CI})$ \\
\hline \multicolumn{5}{|l|}{ Antenatal care } \\
\hline No & $22(45.8)$ & 1.0 & $7(41.2)$ & 1.0 \\
\hline Yes & $321(50.9)$ & $\begin{array}{r}1.2 \\
(0.7-2.2)\end{array}$ & $479(60.6)$ & $\begin{array}{r}2.2 \\
(0.8-5.8)\end{array}$ \\
\hline \multicolumn{5}{|l|}{ Place of delivery } \\
\hline Private clinic & $200(66.2)$ & $\begin{array}{r}2.2^{*} \\
(1.5-3.1)\end{array}$ & $298(64.6)$ & $\begin{array}{r}1.1 \\
(0.8-1.5)\end{array}$ \\
\hline Hospital & $101(47.6)$ & 1 & $143(63.3)$ & 1 \\
\hline \multicolumn{5}{|l|}{ Postpartum care } \\
\hline No & $92(43.8)$ & 1 & $58(50.4)$ & 1.0 \\
\hline Yes & $247(54.1)$ & $\begin{array}{r}1.5^{*} \\
(1.1-2.1)\end{array}$ & $427(62.8)$ & $\begin{array}{r}1.6^{*} \\
(1.1-2.5)\end{array}$ \\
\hline
\end{tabular}

*statistically significant using the $\chi^{2}$ test, " statistically significant using Fisher's exact test

$C I=$ confidence interval; $C S=$ caesarean section; $O R=$ odds ratio.

documented in the EDHS 2008 (9) and EDHS 2014 (6) and Saudi Arabia (2002-2011) (23), where it may be explained by the younger age of these women.

The use of antenatal and postnatal care services was higher in CS deliveries, which was similar to that found in previous studies in Nigeria in 2013 (19), India in 2011 (17), and sub-Saharan Africa (2008-2016) (24). The reason for this is the need for follow-up on the CS incision site in the postpartum period and the need to use family planning methods. It may also be due to a history of a complicated pregnancy or a previous history of CS, which leads the doctor to advise the mother on the necessity for a follow-up visit.

Despite the fact that our study used a large sample size and nationally representative data from 6 governorates in Upper and Lower Egypt identified as underdeveloped or having suboptimal health indicators, the data lacked information on clinical indications for CS and did not differentiate between elective and emergency CSs, $\mathrm{CS}$ on maternal request, pregnancy following in vitro fertilization, repeated CS, and clinicians' preference. And CS should not be considered a weakness, because examining clinical variables was outside the scope of the survey, which aimed to measure the prevalence of CS and identify its sociodemographic characteristics. Therefore, future studies are needed to examine clinical variables to determine if they affect the rate of CS.

\section{Conclusion}

We found a high prevalence of CS as an important health indicator in 6 governorates in Egypt. Residence in Lower Egypt, young maternal age, high maternal education level, high socioeconomic level, and women who had given birth to $\leq 3$ children were significantly associated with a higher prevalence of CS. Efforts should be made to limit inappropriate CS. Therefore, an awareness campaign highlighting the drawbacks of CS is crucial. Furthermore, the alleviation of fears associated with vaginal delivery should be encouraged during antenatal care visits.

\section{Acknowledgement}

The authors gratefully acknowledge receiving funding from the NPC to carry out this survey. We thank CAPMAS for providing the sample units from different governorates.

\section{Funding: None.}

Competing interests: None declared. 


\section{Tendances à la hausse de la césarienne dans six gouvernorats égyptiens}

\section{Résumé}

Contexte : La césarienne est une opération qui permet de sauver des vies lorsque l'accouchement par voie basse présente des risques pour la mère ou le bébé. Cependant, si elle n'est pas médicalement indiquée ou si elle est pratiquée dans des conditions sous-optimales, elle peut s'avérer néfaste et nécessiter des ressources importantes.

Objectifs : Estimer la prévalence de la césarienne dans six gouvernorats égyptiens et identifier les facteurs de risque possibles (y compris les facteurs démographiques, sociaux et ceux liés aux services de santé) stratifiés selon les zones géographiques.

Méthodes: Nous avons utilisé des données secondaires recueillies lors d'une vaste enquête menée pour étudier les indicateurs sociodémographiques et sanitaires de six gouvernorats égyptiens sélectionnés à dessein et présentant des indicateurs sanitaires sous-optimaux : trois de la Haute Égypte (Sohag, Assiout et Minya) et trois de la Basse Égypte (Sharkia, Beheira et Ismailia). Les données de l'enquête ont été recueillies à l'aide d'un questionnaire d'entretien ciblant les membres du ménage.

Résultats : Le taux de césarienne a été estimé à $55,1 \%$ pour les trois années précédant l'étude, et le taux le plus élevé et le plus faible était de $67,8 \%$ et $49,0 \%$ à Behira et Assiout respectivement. Dans la plupart des gouvernorats, le taux de césarienne était plus élevé dans les zones rurales que dans les zones urbaines, mais la différence n'était pas significative. Les taux élevés de césarienne étaient liés de manière significative à une classe sociale plus élevée et à un nombre d'enfants plus faible (inférieur ou égal à trois).

Conclusion: Dans les gouvernorats enquêtés, la césarienne était plus fréquente, avec des taux plus élevés que ceux rapportés dans l'enquête sur les problèmes de santé en Égypte de 2015. L'adoption de protocoles relatifs aux césariennes électives devrait faire l'objet d'un effort plus multisectoriel. Les femmes enceintes doivent également être bien informées sur le risque associé à la césarienne et ses indications médicales.

$$
\begin{aligned}
& \text { الجاهات صاعدة في نمط الولادة في } 6 \text { محافظات مصرية } \\
& \text { مها و هدان، سالي حكيم، مها الغفاري، داليا سوس، غادة واصف، وفاء حسين، أماني خختار، عمرو حسين، محمد العوضي، ميرفت راضي، وجيدة }
\end{aligned}
$$

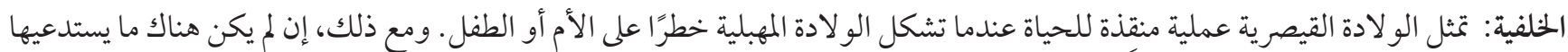

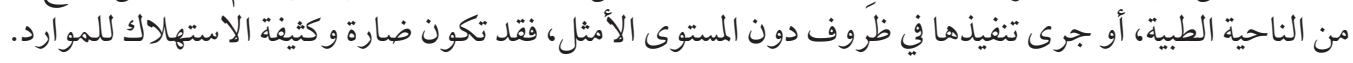

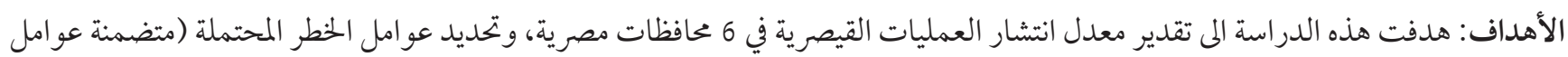

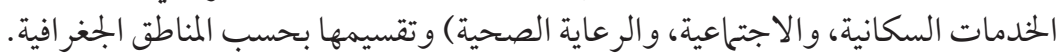

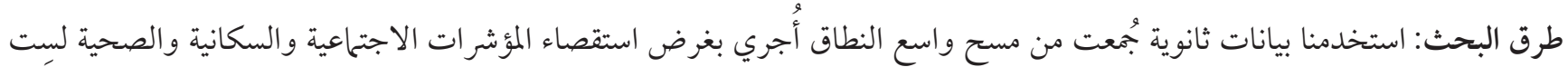

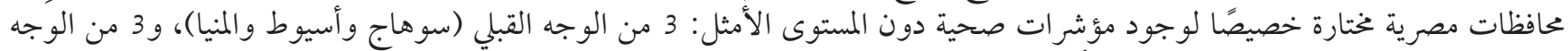

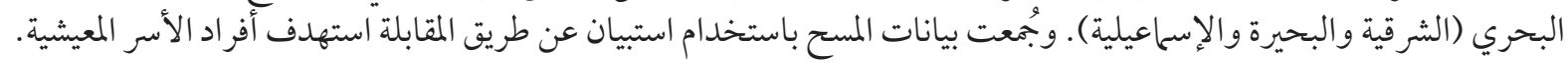

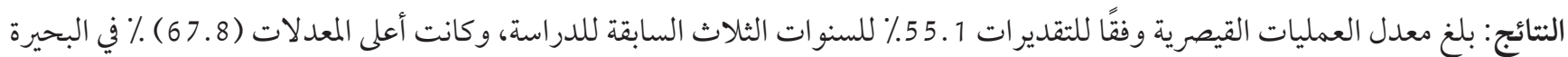

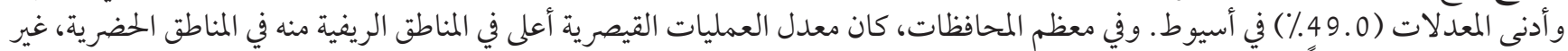

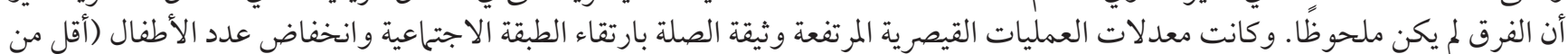

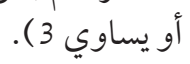

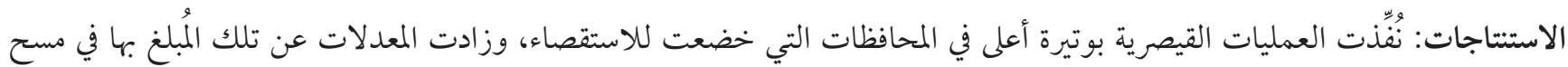

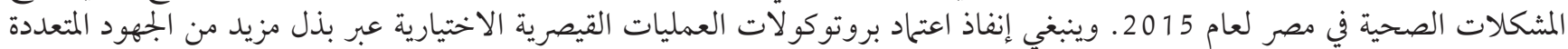
القطاعات. أيضًا ينبني إطلاع النساء الحوامل بشكُل وافٍ على خطر الو لادة القيصرية ودو اعيها الطبية. 


\section{References}

1. Alhabib S, Nur U, Jones R. Domestic violence against women: systematic review of prevalence studies. J Fam Violence. 2010;25(4):369-82. https://doi.org/10.1007/s10896-009-9298-4

2. Global and regional estimates of violence against women: prevalence and health effects of intimate partner violence and non-partner sexual violence. Geneva: World Health Organization; 2013 (https://apps.who.int/iris/handle/10665/85239, accessed 6 December 2013).

3. Tabassum NR, Azim S, Bhuiya A, Ake Persson L. Physical violence by husbands: magnitude, disclosure and help-seeking behaviour of women in Bangladesh. Soc Sci Med. 2006;62(12):2917-29. https://doi.org/10.1016/j.socscimed.2005.12.001

4. Diop-Sidibé N, Campbell JC, Becker S. Domestic violence against women in Egypt - wife beating and health outcomes. Soc Sci Med. 2006;62(5):1260-77. https://doi.org/10.1016/j.socscimed.2005.07.022

5. Western D. Gender-based violence and depression in women: a feminist group work response. Berlin: Springer Science \& Business; 2013.

6. Golmakani N. Domestic violence in pregnancy, outcomes and strategies: a review article. Iran J Obs Gynecol Infertil. 2013;15(42):13-22. https://doi.org/10.22038/IJOGI.2013.571

7. Kamali M, Rahimi Kian F, Mir Mohamad Ali M, Mehran A, Shafiei E. Comparison of domestic violence and its related factors in pregnant women in both urban and rural population in Zarand city, 2014. J Clin Nurs Midwif, 2015;4(2):69-78.

8. Davoudi F, Rasoulian M, Ahmadzad Asl M, Nojomi M. Factors associated with physical domestic violence against women in countries of Eastern Mediterranean Region (EMR): a systematic review and metanalysis. Iran J Psych Clin Psychol. 2013;18(4):261-75.

9. Shuib R, Endut N, Ali SH, Osman I, Abdullah S, Oon SW, et al. Domestic violence and women's well-being in Malaysia: issues and challenges conducting a national study using the WHO multicountry questionnaire on women's health and domestic violence against women. Proceed Soc Behav Sci. 2013;91:475-88. https://doi.org/10.1016/j.sbspro.2013.08.445

10. Douki S, Nacef F, Belhadj A, Bouasker A, Ghachem R. Violence against women in Arab and Islamic countries. Arch Womens Ment Health. 2003;6:165-71. https://doi.org/10.1007/s00737-003-0170-x

11. Status of Arab women report 2017. Violence against women: what is at stake? Beirut: United Nations Economic and Social Commission for Western Asia; 2017:3

12. Hajnasiri H, Ghanei Gheshlagh R, Sayehmiri K, Moafi F, Farajzadeh M. Domestic violence among Iranian women: a systematic review and meta-analysis. Iran Red Crescent Med J. 2016;18(6):e34971. https://doi.org/10.5812/ircmj.34971

13. Pournaghash-Tehrani S. Domestic violence in Iran: a literature review. Aggress Violent Behav. 2011;16:1-5. https://doi. org/10.1016/j.avb.2010.12.001

14. Gelles RJ. Public policy for violence against women 30 years of successes and remaining challenges. Am J Prev Med. 2000;19(4):298-301. https://doi.org/10.1016/s0749-3797(00)00245-2

15. Polit DF, Beck CT. Nursing research: generating and assessing evidence for nursing practice. Ninth edition. Philadelphia: Lippincott Williams \& Wilkins; 2012.

16. Boychuch Duchscher JE, Morgan D. Grounded theory: reflections on the emergence vs forcing debate. J Adv Nurs. 2004;48(6):605-12. https://doi.org/10.1111/j.1365-2648.2004.03249.x

17. Struss A, Corbin JM. Basics of qualitative research: techniques and procedures for developing grounded theory. Thousand Oaks, CA: SAGE Publications Inc.; 1998.

18. Streubert H, Carpenter D. Qualitative research in nursing: advancing the humanistic imperative. Philadelphia: Lippincott Williams \& Wilkins; 2007.

19. Grove SK, Burns N. Understanding nursing research: building an evidence-based practice. Fourth edition. Philadelphia: Saunders Co; 2015.

20. Polit DF, Beck CT. Essentials of nursing research: appraising evidence for nursing practice. Philadelphia: Lippincott Williams and Wilkins; 2010.

21. Amoakohene MI. Violence against women in Ghana: a look at women's perceptions and review of policy and social responses. Soc Sci Med, 2004:59:2373-85. https://doi.org/10.1016/j.socscimed.2004.04.001

22. Marshall GA, Furr LA. Factors that affect women's attitudes toward domestic violence in Turkey. Violence Vict. 2010;25(2):26577. https://doi.org/10.1891/0886-6708.25.2.265

23. Ilika AL. Women's perception of partner violence in a rural Ibgo community. Afr J Reprod Health. 2005;9(3):77-88.

24. Kocacik F, Dogan O. Domestic violence against women in Sivas, Turkey: survey study. Croat Med J. 2006;47(5):742-9.

25. Wu TF, Yeh KH, Cross SE, Larson LM. Conflict with mothers-in-law and Taiwanese women's marital satisfaction: the moderating role of husband support. counselling psychologist, 2010;38(4):497-522. https://doi.org/10.1177/0011000009353071

26. Kaur R, Garg S. Domestic violence against women: a qualitative study in a rural community. Asia Pac J Public Health. 2010;22(2):242-51. https://doi.org/10.1177/1010539509343949 
27. Kalaca S, Dundar P. Violence against women: the perspective of academic women. BMC Public Health. 2010;10:490. https://doi. org/10.1186/1471-2458-10-490

28. Yoshinhama M. Battered women's coping strategies and Psychological distress: differences by immigration status. Am J Community Psychol. 2002;30:429-52. https://doi.org/10.1023/A:1015393204820 